\title{
Epidemiology of invasive fungal diseases on the basis of autopsy reports María Cecilia Dignani ${ }^{1-3}$
}

Addresses: ${ }^{1}$ Registro de Micosis Invasoras REMIIN (Invasive Mycoses' Registry), Yerbal 315 App 2B, 1405, Buenos Aires, Argentina; ${ }^{2}$ Argentinean Society of Infectious Diseases, Av. De Mayo 1370, Floor $11^{\text {th }}$, Of. 300, 1085, Buenos Aires, Argentina; ${ }^{3}$ Italian Hospital of Mendoza, East Access 1070, San José, 5519, Mendoza, Argentina

Email: mcdignani@remiin.com

Fl000Prime Reports 2014, 6:8I (doi:10.12703/P6-8I)

All F1000Prime Reports articles are distributed under the terms of the Creative Commons Attribution-Non Commercial License (http://creativecommons.org/licenses/by-nc/3.0/legalcode), which permits non-commercial use, distribution, and reproduction in any medium, provided the original work is properly cited.

The electronic version of this article is the complete one and can be found at: http://f1000.com/prime/reports/m/6/8 I

\begin{abstract}
Invasive fungal diseases (IFDs) are a major cause of morbidity and mortality among immunocompromised patients and cost to health services. They are difficult to prevent, diagnose, and treat. This difficulty in diagnosis leads us to treat them empirically by using several tools, including epidemiological data, nonculture methods and images. Most of the available epidemiological information may not be accurate because we are dealing with a disease that only has an estimated $50 \%$ chance of being diagnosed before death. Therefore, autopsy reports become a valuable tool, not only to define the real epidemiology, but also to address the trend in pre-mortem diagnosis, which is the best marker available to prove the efficiency of the research in IFD.

This article reviews and analyzes the data on IFD obtained from II single-center, multi-center and nationwide autopsy reports published between 2008 and 2013 , and also discusses the issues we need to address in order to improve the quality of the epidemiological data on invasive fungal disease obtained from autopsy reports.
\end{abstract}

\section{Introduction}

Several registries or other types of epidemiological studies worldwide have looked at the epidemiology of IFDs. The goal of these studies is to provide data that would help the clinician to make a decision when there is a suspicion of an ongoing IFD in a patient at risk but it cannot be documented. However, this poses the question of how we deal with these cases in terms of epidemiology. Currently, only about half or less of these infections are detected before death, even after the development of sophisticated images and non-culture methods for diagnosis. Patients with IFD continue to die, and we continue to miss diagnosing patients with IFD during life. Therefore, the real epidemiology of IFDs should be seen in autopsies. However, there are several major questions. What do the current autopsy reports say worldwide? What is the current expected pre-mortem diagnosis of IFDs? How can we improve the quality of autopsy reports?
IFDs are a major cause of morbidity and mortality among immunocompromised patients, especially in those with oncohematological disorders, solid cancer, recipients of stem cell or solid organ transplantation, and recipients of immunosuppressive agents including a high dose of steroids or anti-tumor necrosis factor therapies (such as infliximab, etanercept, and adalimumab) or anti-inflammatory antibodies. IFDs have the following characteristics: a) they are very difficult to diagnose before death, with rates of pre-mortem diagnosis that go from 12 to 60\% [1-6] (therefore, they should be treated empirically most of the time); b) their epidemiology varies according to geography, nosocomial reservoirs and antifungal exposure (therefore, empirical treatment usually relies on knowledge of the local epidemiology plus clinical findings) [7]; c) they are difficult to treat, having a slow response to costly antifungal agents (e.g. $45 \%$ mortality amongst patients with invasive 
aspergillosis at 12 weeks of therapy [8]); d) they may require surgery; e) treatments are prolonged (from weeks to months or years); f) the delay of their treatment is associated with an increased mortality rate [9]; g) they may relapse after apparent cure if a subsequent period of immunosuppression occurs (in this case, they require longer antifungal treatments for secondary prophylaxis) $[10,11]$; and $h)$ they are associated with a significant increase in costs [12-14].

Autopsies continue to be of great value for complete understanding of the epidemiology and diagnosis of IFD. They determine the presence, organ distribution and type of IFD. In addition, they give us information about an extremely relevant issue in clinical practice: the rate of pre-mortem diagnosis. The final objective of all clinical research into IFD is to decrease mortality resulting from IFDs by increasing their prevention, and their diagnosis during the lifetime of patients.

Despite all of these benefits, autopsy rates have been decreasing worldwide, mainly due to lack of state regulations, cost issues, family preferences, and physician attitudes.

The purpose of this article is to summarize and analyze the current data available on the epidemiology of IFD obtained from autopsy reports published during the last 6 years. By doing so, we aim to promote the value of this tool and point out what needs to be addressed to obtain the best results from it.

A literature search was carried out in PubMed, using the following keywords: autopsy or necropsy, plus mold or fungal infections or mold infections. This search was filtered for humans and for the time period 2008 to February 24th, 2014. Since most autopsy reports do not provide data on culture results, the identification of the genera causing the IFD when hyaline hyphae are identified was not possible. Therefore, the term Aspergillus-like organisms (or culture-negative hyalohyphomycetes) refers to hyaline septated and branching hyphae seen in tissues with histopathology consistent with Aspergillus spp. that were not cultured or were culture negative, and may belong to different genera such as Aspergillus, Fusarium, Paecilomyces, Penicillium, Pseudallescheria boydii, and so on.

\section{Autopsy reports on invasive fungal diseases Overall data}

From 2008 to 2013, 11 single-center, multi-center and nationwide autopsy reports on IFD have been published worldwide in PubMed [1-6,15-19]. These reports include data on 9187 IFDs observed in 193,095 autopsies. These autopsies were done during a cumulative study period of 192 years, in seven countries, and in four types of patient populations (general, oncohematology, stem cell transplant, and acquired immunodeficiency syndrome [AIDS] - Table 1). The median prevalence of IFD is 8.7 per 100 autopsies with a wide range (1.4 to 30.6). Of note, the prevalence of IFD caused by two or more concomitant fungal organisms (mixed IFD) is 4.4 per 100 autopsies (range 0-10.8) (Table 2). This is particularly important from a clinical point of view because most decisions in clinical practice are based on the assumption that the patient has only one IFD. Today, there are several antifungal agents available that have a different spectrum of action. Therefore, clinicians should consider the possibility of more than one infectious agent if there are conflicting microbiological results or a clinical failure when using a certain antifungal agent.

Currently, in contrast to previous decades, the most prevalent etiological agents of IFD are Aspergillus or "Aspergillus-like" organisms followed by Candida spp. (Table 3).

Even though this is a great piece of data, we should be careful at the time of analysis and comparison. These reports differ in their study populations, autopsy rates, methods for diagnosis of IFD, and also in the inclusion of Pneumocystis jirovecii as another IFD. Most reports come from the general population of Japan (because autopsies from the whole country are reported through the Japanese Society of Pathology). About half of the reports include microbiology results (in addition to the pathological stains) for the diagnosis of IFD, or include Pneumocystis jirovecii as another IFD. The median autopsy rate is 15 per 100 deceased patients with a wide range (1.2 to 100).

The information given by these global data is particularly important for the healthcare system (disease load) and for educational purposes (patients still die with or from IFD). It is well known that autopsy reports usually teach physicians how appropriate the diagnosis and treatment approach was before death.

\section{Data according to type of patient population General population}

Six reports conducted in the general population included 8076 IFDs from 188,228 autopsies, with a prevalence of 4.2 to 5 IFDs per 100 autopsies (Table 4) [5,15-19].

The most prevalent etiological agents of IFD are Aspergillus or Aspergillus-like organisms (45-46\% of all IFDs), even in reports where Pneumocystis jirovecii was included in the analysis. The second most prevalent etiological fungal organism was Candida spp. (28-37\%), while the third and fourth places belong to Cryptococcus 
Table I. Autopsy reports on invasive fungal diseases published between 2008 and 2013

\begin{tabular}{|c|c|c|c|c|c|}
\hline Reference & $\begin{array}{l}\text { Study length in years. } \\
\text { (Period) }\end{array}$ & No. of centers. Country & No. of autopsies & $\begin{array}{l}\text { Autopsy rates } \\
\text { (period) }\end{array}$ & Type of population \\
\hline$[\mathrm{I}]$ & $\begin{array}{l}30 \\
(1976-2005)\end{array}$ & $\begin{array}{l}\text { Single-center } \\
\text { Germany }\end{array}$ & I,59| & $\begin{array}{l}16 \%(199 \mid-95) \\
11 \%(200 \mid-5)\end{array}$ & Onco-hematology \\
\hline [2] & $\begin{array}{l}4 \\
(2003-2006)\end{array}$ & $\begin{array}{l}\text { Multi-center (2) } \\
\text { Hungary }\end{array}$ & 38 & $100 \%(2003-2006)$ & Stem cell transplant \\
\hline [3] & $\begin{array}{l}20 \\
(1988-2007)\end{array}$ & $\begin{array}{l}\text { Single-center } \\
\text { USA }\end{array}$ & 395 & $14 \%$ & Stem cell transplant \\
\hline$[4]$ & $\begin{array}{l}18 \\
(1984-2002)\end{array}$ & $\begin{array}{l}\text { Single-center } \\
\text { Italy }\end{array}$ & 1,630 & $33 \%$ & AIDS \\
\hline$[15]$ & $\begin{array}{l}12 \\
(1993-2005)\end{array}$ & $\begin{array}{l}\text { Single-center } \\
\text { Germany }\end{array}$ & 2,707 & $\begin{array}{l}54 \%(1993-96) \\
18 \%(2001-5)\end{array}$ & General \\
\hline$[16]$ & $\begin{array}{l}\text { 6* } \\
(1989-2007)\end{array}$ & $\begin{array}{l}\text { Nationwide } \\
\text { Japan }\end{array}$ & 156,212 & NA & General \\
\hline$[5]$ & $\begin{array}{l}19 \\
(1988-2007)\end{array}$ & $\begin{array}{l}\text { Single-center } \\
\text { India }\end{array}$ & 401 & NA & $\begin{array}{l}\text { General, excluding } \\
\text { HIV and legal issues }\end{array}$ \\
\hline$[17]$ & $\begin{array}{l}10 \\
(2000-2009)\end{array}$ & $\begin{array}{l}\text { Multi-center } \\
\text { Brazil }\end{array}$ & 4,824 & NA & General \\
\hline$[18]$ & $\begin{array}{l}52 \\
(1955-2006)\end{array}$ & $\begin{array}{l}\text { Multi-center (2) } \\
\text { Japan }\end{array}$ & 10,297 & $\begin{array}{l}50 \%(1983) \\
10 \%(2006)\end{array}$ & General \\
\hline$[19]$ & (2009) & $\begin{array}{l}\text { Nationwide } \\
\text { Japan }\end{array}$ & 13,787 & I.2\% (2009) & General \\
\hline [6] & $\begin{array}{l}20 \\
(1989-2008) \\
\text { Total } \\
192 \text { years }\end{array}$ & $\begin{array}{l}\text { Single-center } \\
\text { USA } \\
\text { Total } \\
7 \text { countries }\end{array}$ & $\begin{array}{l}1,213 \\
\text { Total } \\
193,095\end{array}$ & $\begin{array}{l}0.6 \%(1989-93) \\
0.06 \%(2004-8) \\
\text { Median (range) } \\
15 \%(0.06-100)\end{array}$ & Onco-hematology \\
\hline
\end{tabular}

* Years 1989, 1993, 1997, 2001, 2005 and 2007.

Abbreviations: AIDS, acquired immunodeficiency syndrome; HIV, human immunodeficiency virus; NA, not available.

Table 2. Prevalence of invasive fungal diseases from autopsy reports published between 2008 and 2013

\begin{tabular}{|c|c|c|c|c|c|c|}
\hline Reference & No. of autopsies & Diagnosis IFD & With PCP & No. of IFDs & Autopsies with IFD \% & No. of mixed IFDs (\%)* \\
\hline [I] & $159 \mid$ & Path & No & 340 & 21.4 & $25(7)$ \\
\hline [2] & 38 & Path + Micro & No & 10 & 26.3 & 0 \\
\hline [3] & 395 & Path + Micro & Yes & 93 & 23.5 & $10(\mathrm{II})$ \\
\hline [4] & 1630 & Path & Yes & 297 & 18.2 & $9(3)$ \\
\hline [I5] & 2707 & Path & Yes & 221 & 8.2 & $22(10)$ \\
\hline [16] & 156,212 & Path & No & 6709 & 4.3 & $261(4)$ \\
\hline [5] & 401 & Path + Micro & Yes & 35 & 8.7 & $2(6)$ \\
\hline [17] & 4824 & Path & No & 67 & 1.4 & $2(3)$ \\
\hline [18] & 10,297 & Path & Yes & $4 I I$ & 4 & $18(4)$ \\
\hline [19] & 13,787 & Path + Micro & No & 633 & 4.6 & $23(4)$ \\
\hline \multirow[t]{5}{*}{ [6] } & 1213 & Path + Micro & No & 371 & 30.6 & $19(5)$ \\
\hline & Total & Path only: 6 & No: 6 & Total & Median & Median \\
\hline & 193,095 & Path + Micro: 5 & Yes: 5 & 9187 & $8.7 \%$ & $4.4 \%$ \\
\hline & & & & & Range & Range \\
\hline & & & & & $1.4-30.6 \%$ & $0-10.8 \%$ \\
\hline
\end{tabular}

* \% of mixed IFD refers to the proportion of all IFDs that are caused by 2 or more concomitant fungal organisms.

Abbreviations: IFD, invasive fungal disease; Micro, microbiology; Path, pathology; PCP, Pneumocystis jirovecii pneumonia.

spp. (4-19\%), and agents of mucormycosis (2.6-8.3\%), respectively. The percentages of etiological agents were calculated including only IFDs caused by a single organism.

\section{Oncohematological population}

These studies include 711 IFDs from 2804 autopsies, with a prevalence much higher than observed in the general population (25 per 100 autopsies). This is expected because oncohematological patients have the highest risk for development of IFD (Table 4) [1,6].
The most prevalent etiological agents of IFD are Aspergillus or Aspergillus-like organisms (55.5\%), followed by Candida spp. (28.5\%) and agents of mucormycosis $(6 \%)$. In these two reports, diseases caused by Pneumocystis jirovecii were not included. Microbiological information was used for diagnosis in one study only [6].

Stem cell transplant population

These two studies include 103 IFDs from 433 autopsies, with an expected high prevalence of IFD (24 per 100 autopsies) (Table 4) [2,3]. 
Table 3. Etiological agents of invasive fungal diseases from autopsy reports published between 2008 and 2013

\begin{tabular}{|c|c|c|c|}
\hline Reference & Most prevalent IFD (\%)* & $2^{\text {nd }}$ most prevalent IFD (\%) & $\%$ of IFD causing death (period) \\
\hline$[1]$ & $\begin{array}{l}\text { Aspergillus-like } \\
\text { (55) }\end{array}$ & $\begin{array}{l}\text { Candida } \\
(34)\end{array}$ & $\begin{array}{l}30(1996-2000) \\
21(200 I-2005)\end{array}$ \\
\hline [2] & $\begin{array}{l}\text { Aspergillus } \\
(60)\end{array}$ & $\begin{array}{l}\text { Candida } \\
(20) \\
\text { Mucormycosis }(20)\end{array}$ & $26(2003-2006)$ \\
\hline [3] & $\begin{array}{l}\text { Aspergillus + Aspergillus-like } \\
\text { (73) }\end{array}$ & $\begin{array}{l}\text { Candida } \\
(35)\end{array}$ & $\begin{array}{l}30(1988-1992) \\
\text { II }(2003-2007)\end{array}$ \\
\hline [4] & $\begin{array}{l}\text { PCP } \\
(45)\end{array}$ & $\begin{array}{l}\text { Aspergillus } \\
\text { (29) }\end{array}$ & 35 (1984-2002) \\
\hline$[15]$ & Aspergillus-like** & Candida & NA \\
\hline [16] & $\begin{array}{l}\text { Aspergillus-like } \\
(4 \mathrm{I})\end{array}$ & $\begin{array}{l}\text { Candida } \\
\text { (36) }\end{array}$ & NA** \\
\hline [5] & $\begin{array}{l}\text { Aspergillus } \\
(55)\end{array}$ & $\begin{array}{l}\text { Mucormycosis } \\
\text { (15) }\end{array}$ & NA \\
\hline [17] & $\begin{array}{l}\text { Cryptococcosis } \\
(45)\end{array}$ & $\begin{array}{l}\text { Paracoccidioidomycosis } \\
\text { (28) }\end{array}$ & NA \\
\hline$[18]$ & $\begin{array}{l}\text { Candida } \\
\text { (54) }\end{array}$ & $\begin{array}{l}\text { Aspergillus-like } \\
\text { (27) }\end{array}$ & NA \\
\hline [19] & $\begin{array}{l}\text { Aspergillus } \\
\text { (49) }\end{array}$ & $\begin{array}{l}\text { Candida } \\
(30)\end{array}$ & NA \\
\hline [6] & $\begin{array}{l}\text { Aspergillus + Aspergillus-like } \\
\text { (56) }\end{array}$ & $\begin{array}{l}\text { Candida } \\
\text { (23) }\end{array}$ & $\begin{array}{l}70-80 \text { (prior to 2004) } \\
49(2004-2008)\end{array}$ \\
\hline
\end{tabular}

Aspergillus-like refers to culture negative hyalohyphomycosis or hyaline hyphae not consistent with mucormycosis; $* \%$ of the most prevalent IFD refers to the proportion of all IFDs caused by a single organism; ** \% was not mentioned in the article; however, it can be estimated from the figures that the approximate values were $55 \%$ for aspergillosis and $40 \%$ for candidiasis.

Abbreviation: IFD, invasive fungal disease.

The most prevalent etiological agents of IFD are Aspergillus or Aspergillus-like organisms (66.5\%), followed by Candida spp. (27.5\%) and agents of mucormycosis $(12.5 \%)$. Both reports included microbiological data for the diagnosis of IFD and only one included Pneumocysits jirovecii [3]. The ranking order of genera is similar to the one seen in the oncohematological population, with a higher percentage of mucormycosis.

\section{AIDS population}

Only one autopsy report exclusively studied IFD in the AIDS population (Table 4) [4]. It includes 297 IFDs from 1630 autopsies, with a prevalence of 18 IFDs per 100 autopsies. This report, as expected, includes Pneumocysitis jirovecii and uses only pathology stains for the diagnosis of IFD.

The most prevalent etiological agents of IFD are Pneumocystis jirovecii (45\%), followed by Aspergillus-like (29\%), Cryptococcus (22\%) and Candida spp. (5\%). The ranking order of genera is completely different from the other study populations, and this is due to the unique susceptibility of AIDS patients to infections by Pneumocystis jirovecci and Cryptococcus. Of note, it is important to see the unexpectedly high prevalence of aspergillosis.

Pre-mortem diagnosis of invasive fungal diseases Six autopsy reports of IFDs give data on pre-mortem diagnosis of these infections during nine study periods
(Table 5) [1-6]. The median pre-mortem diagnosis is 46 per 100 autopsies with IFD, with a wide range that goes from 16 to 60 . Two studies report an improvement of these values after 20 years $[1,6]$, while one study shows the same rate of pre-mortem diagnosis after 10 years [3].

Pre-mortem diagnosis may vary according to the etiology of the IFD, as is shown in one study, where, among AIDS patients, the likelihood of diagnosing invasive aspergillosis or mucormycosis (a less expected IFD in this setting) before death is very low ( $12 \%$ and $0 \%$, respectively) [4].

One interesting finding is that in one study conducted among oncohematological patients, almost half of patients with aspergillosis proven by autopsy had had repeatedly negative galactomannan in serum before death [6]. This finding highlights and supports the different findings in many centers regarding the value of galactomannan in the diagnosis of invasive aspergillosis.

\section{Current trends obtained from autopsy reports in invasive fungal diseases}

Looking at all the reports in aggregate, some trends emerge that are common to most of them. These trends include the following: a) a decrease in autopsy rates; b) an increase in the prevalence of IFD in the 1990s, and then a decrease from the 2000s; c) a decrease in the population with IFD and oncohematological disorders, 
Table 4. Prevalence of invasive fungal diseases from autopsy reports published between 2008 and 2013 according to type of population studied

\begin{tabular}{|c|c|c|c|}
\hline $\begin{array}{l}\text { Type of } \\
\text { population }\end{array}$ & $\begin{array}{l}\text { No. of } \\
\text { autopsies }\end{array}$ & $\begin{array}{l}\text { No. of IFDs } \\
(\%)^{*}\end{array}$ & $\begin{array}{l}\text { Most prevalent } \\
\text { organism (\%)** }\end{array}$ \\
\hline $\begin{array}{l}\text { General } \\
\text { With PCP **** } \\
{[5,15,18]}\end{array}$ & 13,405 & $667(5)$ & $\begin{array}{l}\text { Aspergillus + } \\
\text { Aspergillus-like } \\
\text { (46) } \\
\text { Candida } \\
\text { (37) } \\
\text { Mucormycosis } \\
\text { (8.3) } \\
\text { Cryptococcus } \\
\text { (4) }\end{array}$ \\
\hline$\frac{\text { Without PCP }}{[16,17,19]}$ & 174,823 & $7409(4.2)$ & $\begin{array}{l}\text { Aspergillus } \\
(45)^{* * * * * *} \\
\text { Candida } \\
(28) \\
\text { Cryptococcus } \\
(19) \\
\text { Paracoccidioides } \\
\text { (9.3) } \\
\text { Mucormycosis } \\
(2.6)\end{array}$ \\
\hline $\begin{array}{l}\text { AIDS [4] (PCP } \\
\text { included) }\end{array}$ & 1,630 & 297 (I8) & $\begin{array}{l}\text { PCP } \\
(45) \\
\text { Aspergillus } \\
\text { (29) } \\
\text { Cryptococcus } \\
\text { (22) } \\
\text { Candida } \\
\text { (5) }\end{array}$ \\
\hline $\begin{array}{l}\text { Stem cell transplant } \\
\text { (PCP included in I) } \\
{[2,3]}\end{array}$ & 433 & $103(24)$ & $\begin{array}{l}\text { Aspergillus + } \\
\text { Aspergillus-like } \\
(66.5) \\
\text { Candida } \\
\text { (27.5) } \\
\text { Mucormycosis } \\
(12.5)\end{array}$ \\
\hline $\begin{array}{l}\text { Oncohematology } \\
\text { (PCP not included) } \\
{[1,6]}\end{array}$ & 2804 & 7II (25) & $\begin{array}{l}\text { Aspergillus }+ \\
\text { Aspergillus-like } \\
\text { (55.5) } \\
\text { Candida } \\
\text { (28.5) } \\
\text { Mucormycosis } \\
(6)\end{array}$ \\
\hline
\end{tabular}

$*$ includes mixed IFD; $* *$ to calculate this percentage, mixed infections were excluded; *** one study excluded HIV patients [5]; **** data on aspergillosis only available for 2 studies $[16,19]$.

Abbreviations: IFD, invasive fungal diseases; PCP, Pneumocystis jirovecii pneumonia.

and an increase in patients with collagenous or respiratory disease; d) a decrease in patients with IFD and neutropenia and an increase in patients receiving corticosteroids or anti-tumor necrosis factor therapies; e) a higher prevalence of IFD in patients older than 40 and younger than 1 ; $f$ ) an increase of mucormycosis in the adult population and also in infants less than 1 year old; $g$ ) the emergence of mixed mold infections since the 2000s (mucormycosis plus aspergillosis); h) a decrease in severe cases of candidiasis and aspergillosis, while the prevalence of severe cases of mucormycosis remains high $(>70 \%)$; i) a decrease in mortality attributed to IFD; and j) an increased rate of premortem diagnosis.

\section{Conclusions}

After reviewing 11 single-center, multi-center and nationwide autopsy reports on IFD, we can answer our initial questions.

\section{What do the current autopsy reports say worldwide?}

The current worldwide autopsy reports say that IFDs have a median prevalence of 9 per 100 autopsies, being highest among patients with hematological disorders or stem cell transplantation. The top three etiological agents are Aspergillus-like organisms (meaning culture negative hyalohyphomycetes plus confirmed Aspergillus spp.) followed by Candida spp. and agents of mucormycosis. It is interesting to see the emergence of mucormycosis in patients younger than 1 year old across different centers and the high prevalence of invasive aspergilosis in autopsies of AIDS patients.

\section{What is the current expected pre-mortem diagnosis of invasive fungal disease?}

The current expected pre-mortem diagnosis of IFD is 46 patients per 100 autopsies, and this may vary according to the etiology of the IFD and the type of underlying disease of the deceased patient. Therefore, in 2013, we still missed the diagnosis in around half of IFDs. However, we should also consider that this number might be higher in reality since the percentage of patients with IFDs diagnosed only at autopsy might have been biased by including patients in terminal stages of chronic underlying diseases in which diagnostic procedures were not performed (as changes would not have been made in patient management).

\section{How can we improve the quality of autopsy reports in autopsied patients?}

The quality of data on IFD obtained from autopsy reports can certainly be improved by addressing the following issues: a) establishing standard procedures for diagnosis (pathology and microbiology or pathology and polymerase chain reaction (PCR) [20] plus clinical information); b) establishing standard inclusion criteria (with or without including Pneumocystis jirovecii disease); and c) increasing the autopsy rate over the suggested minimum of $30 \%$ [21].

Addressing item a) would allow us to obtain microbiological information that would clarify the group of culture negative hyalohyphomycetes, since this group 
Table 5. Pre-mortem diagnosis of invasive fungal diseases: review of autopsy reports published between 2008 and 2013

\begin{tabular}{llll}
\hline Reference & Period & $\begin{array}{l}\text { Pre-mortem } \\
\text { diagnosis IFD }\end{array}$ & Comments \\
\hline$[1]$ & $1976-1983$ & $30 \%$ & Statistical analysis not available \\
{$[2]$} & $1998-2005$ & $42 \%$ & none \\
{$[3]$} & $2003-2006$ & $60 \%$ & none \\
{$[4]$} & $1988-1997$ & $50 \%$ & $>$ cryptococcosis $(95 \%)>P C P(50 \%)>$ histoplasmosis $(25 \%)$ \\
{$[5]$} & $1998-2007$ & $53 \%$ NS & $>$ candidiasis $(20 \%)>$ aspergillosis $(12 \%)>$ mucormycosis $(0)$ \\
{$[6]$} & $1984-2002$ & $46 \%$ NS over time & none \\
& $1988-2007$ & $20 \%$ & $5 / I$ I $(45 \%)$ of aspergillosis proven cases had repeatedly \\
\end{tabular}

Abbreviations: IFD, invasive fungal diseases; NS, not significant; PCP, Pneumocystis jirovecii pneumonia.

may include several emergent opportunistic fungi that are frequently found in other types of epidemiological studies, and that may have differences in susceptibility to antifungal agents. Addressing item b) would allow us to compare with more accuracy the prevalence of IFD in different populations. Addressing item c) would allow us to extrapolate with more accuracy the data obtained from one autopsy report to the whole population. Some autopsy procedures can certainly include reliable microbiology data by either adding microbiology results obtained before death to the final report or by getting new samples for microbiology data immediately after death.

Finally, this review of IFD from autopsy reports tells us that, despite all our efforts in prevention, diagnosis and treatment, IFDs still have a significant prevalence and are associated with a low pre-mortem diagnosis. In the future, the improvement of autopsy studies (as mentioned earlier) could make them become the fastest and most reliable tool for understanding the epidemiology of IFD. In addition, as has been previously suggested [21], they could also be seriously considered as a quality control tool.

\section{Abbreviations}

AIDS, acquired immunodeficiency syndrome; IFD, invasive fungal disease.

\section{Disclosures}

The author declares that she has no disclosures.

\section{References}

I. Donhuijsen K, Petersen P, Schmid WK: Trend reversal in the frequency of mycoses in hematological neoplasias: autopsy results from 1976 to 2005. Dtsch Arztebl Int 2008, 105:50I-6.

\section{FlOOOPrime} RECOMMENDED

2. Sinkó J, Csomor J, Nikolova R, Lueff S, Kriván G, Reményi P, Bátai A, Masszi T: Invasive fungal disease in allogeneic hematopoietic stem cell transplant recipients: an autopsy-driven survey. Transpl Infect Dis 2008, 10:106-9.

\section{FIOOOPrime}

RECOMMENDED

3. Alsharif M, Cameron, Stuart EH, Young JH, Savik K, Henriksen JC, Gulbahce HE, Pambuccian SE: Time trends in fungal infections as a cause of death in hematopoietic stem cell transplant recipients: an autopsy study. Am J Clin Pathol 2009, I32:746-55.

\section{FlOOOPrime}

\section{RECOMMENDED}

4. Antinori S, Nebuloni M, Magni C, Fasan M, Adorni F, Viola A, Corbellino M, Galli M, Vago G, Parravicini C, Ridolfo AL: Trends in the postmortem diagnosis of opportunistic invasive fungal infections in patients with AIDS: a retrospective study of I,630 autopsies performed between 1984 and 2002. Am J Clin Pathol 2009, I32:221-7.

\section{FlOOOPrime
RECOMMENDED}

5. Uppin MS, Anuradha SVN, Uppin SG, Paul TR, Prayaga AK, Sundaram C: Fungal infections as a contributing cause of death: an autopsy study. Indian J Pathol Microbiol 201 I, 54:344-9.

\section{FlOOOPrime}

6. Lewis RE, Cahyame-Zuniga L, Leventakos K, Chamilos G, Ben-Ami R, Tamboli P, Tarrand J, Bodey GP, Luna M, Kontoyiannis DP: Epidemiology and sites of involvement of invasive fungal infections in patients with haematological malignancies: a 20year autopsy study. Mycoses 2013, 56:638-45.

\section{FlOOOPrime
RECOMMENDED}

7. Pagano L, Caira M, Nosari A, Cattaneo C, Fanci R, Bonini A, Vianelli N, Garzia MG, Mancinelli M, Tosti ME, Tumbarello M, Viale P. Aversa F, Rossi G: The use and efficacy of empirical versus preemptive therapy in the management of fungal infections: the HEMA e-Chart Project. Haematologica 20II, 96:1366-70.

\section{FlOOOPrime}

\section{RECOMMENDED}

8. Lortholary O, Gangneux J, Sitbon K, Lebeau B, Monbrison F de, Le Strat $Y$, Coignard B, Dromer F, Bretagne S: Epidemiological trends in invasive aspergillosis in France: the SAIF network (20052007). Clin Microbiol Infect 20I I, I7:1882-9.

\section{FlOOOPrime RECOMMENDED}

9. Greene RE, Schlamm HT, Oestmann J, Stark P, Durand C, Lortholary O, Wingard JR, Herbrecht R, Ribaud P, Patterson TF, Troke PF, Denning DW, Bennett JE, de Pauw, Ben E, Rubin RH: 
Imaging findings in acute invasive pulmonary aspergillosis: clinical significance of the halo sign. Clin Infect Dis 2007, 44:373-9.

\section{FlOOOPrime}

10. Sipsas NV, Kontoyiannis DP: Clinical issues regarding relapsing aspergillosis and the efficacy of secondary antifungal prophylaxis in patients with hematological malignancies. Clin Infect Dis 2006, 42:|584-9|.

\section{FlOOOPrime}

\section{RECOMMENDED}

II. Cordonnier C, Rovira M, Maertens J, Cornely OA, Ljungman P, Einsele $\mathrm{H}$ : Voriconazole as secondary antifungal prophylaxis in stem cell transplant recipients. Haematologica 20II, 96:e9-10; author reply el I.

12. Dasbach EJ, Davies GM, Teutsch SM: Burden of aspergillosisrelated hospitalizations in the United States. Clin Infect Dis 2000, 31:1524-8.

13. Menzin J, Meyers JL, Friedman M, Perfect JR, Langston AA, Danna RP, Papadopoulos G: Mortality, length of hospitalization, and costs associated with invasive fungal infections in high-risk patients. Am J Health Syst Pharm 2009, 66: 17II-7.

14. Menzin J, Meyers JL, Friedman M, Korn JR, Perfect JR, Langston AA, Danna RP, Papadopoulos G: The economic costs to United States hospitals of invasive fungal infections in transplant patients. Am J Infect Control 20I I, 39:el5-20.

15. Lehrnbecher T, Frank C, Engels K, Kriener S, Groll AH, Schwabe D: Trends in the postmortem epidemiology of invasive fungal infections at a university hospital. J Infect 2010, 6I:259-65.

\section{FlOOOPrime \\ FEOMMENDED}

16. Kume H, Yamazaki T, Togano T, Abe M, Tanuma H, Kawana S, Okudaira M: Epidemiology of visceral mycoses in autopsy cases in Japan: comparison of the data from 1989, 1993, 1997, 200I,
2005 and 2007 in Annual of Pathological Autopsy Cases in Japan. Med Mycol J 20I I, 52:1 I7-27.

FlOOOPrime

17. Colombo TE, Soares, Márcia Maria Costa Nunes, D’Ávilla Solange Corrêa Garcia Pires, Nogueira, Mara Correa Lelles, de Almeida, Margarete Teresa Gottardo: Identification of fungal diseases at necropsy. Pathol Res Pract 20I2, 208:549-52.

\section{FlOOOPrime}

18. Shimodaira K, Okubo Y, Nakayama H, Wakayama M, Shinozaki M, Ishiwatari T, Sasai D, Nemoto T, Takahashi K, Ishii T, Saji T, Shibuya K: Trends in the prevalence of invasive fungal infections from an analysis of annual records of autopsy cases of Toho University. Mycoses 2012, 55:435-43.

\section{FlOOOPrime \\ RECOMMENDED}

19. Suzuki Y, Kume H, Togano T, Kanoh Y, Ohto H: Epidemiology of visceral mycoses in autopsy cases in Japan: the data from 1989 to 2009 in the Annual of Pathological Autopsy Cases in Japan. Med Mycol 2013, 51 1:522-6.

\section{FlOOOPrime}

20. Rickerts V, Mousset S, Lambrecht E, Tintelnot K, Schwerdtfeger R, Presterl E, Jacobi V, Just-Nübling G, Bialek R: Comparison of histopathological analysis, culture, and polymerase chain reaction assays to detect invasive mold infections from biopsy specimens. Clin Infect Dis 2007, 44:1078-83.

\section{FlOOOPrime
RECOMMENDED}

21. Schwarze EW: Die Bedeutung der Autopsie-heute und morgen. Verh Dtsch Ges Pathol 200I, 85: I 18-3I. 